\title{
http://jos.unsoed.ac.id/index.php/jpbsi/index
}

\section{Implikatur Percakapan dalam Film Orang Kaya Baru sebagai Bahan Ajar Teks Anekdot Kelas X}

\author{
Widia Siska Maerice $^{1)}$, Dyah Wijayawati ${ }^{2)}$, Bivit Anggoro Prasetyo Nugroho ${ }^{3)}$ \\ 1)Pendidikan Bahasa dan Sastra Indonesia Universitas Jenderal Soedirman \\ E-mail: widia.maerice@mhs.unsoed.ac.id \\ 2) Pendidikan Bahasa dan Sastra Indonesia Universitas Jenderal Soedirman \\ E-mail: dyah.wijayawati@unsoed.ac.id \\ 3) Pendidikan Bahasa dan Sastra Indonesia Universitas Jenderal Soedirman \\ E-mail: bivit.nugroho@unsoed.ac.id
}

\begin{abstract}
Abstrak
Penelitian ini berbentuk deskriptif kualitatif yang bertujuan untuk mendeskripsikan wujud pelanggaran prinsip kerja sama dan prinsip kesantunan dalam film Orang Kaya Baru, mendeskripsikan makna implikatur yang terkandung dalam film Orang Kaya Baru, dan mendeskripsikan implementasinya dalam pembelajaran teks anekdot. Metode pengumpulan data dalam penelitian ini menggunakan metode simak dengan teknik dasar sadap dan teknik lanjutannya teknik simak bebas libat cakap dan teknik catat. Pada tahap analisis data, peneliti menggunakan metode padan dengan teknik dasar pilah unsur penentu menggunakan daya pilah pragmatis, dan teknik lanjutan hubung banding memperbedakan. Adapun hasil analisis data disajikan dengan metode informal. Berdasarkan analisis data, terdapat pelanggaran pada setiap maksim dalam prinsip kerja sama dan prinsip kesantunan. Pelanggaran maksim-maksim tersebut menjadi penyebab munculnya implikatur percakapan dalam film Orang Kaya Baru. Adanya pelanggaran tersebut juga memberikan manfaat bagi pembaca, khususnya siswa. Melalui pemahaman tentang pelanggaran prinsip percakapan, diharapkan pembaca dapat menggunakan prinsip percakapan yang sesuai dalam berkomunikasi. Pemahaman mengenai implikatur dapat digunakan sebagai bahan ajar untuk mencapai tujuan pembelajaran pada Kompetensi Dasar (KD) 3.5 yaitu mengevaluasi teks anekdot dari aspek makna tersirat.
\end{abstract}

Kata Kunci: film Orang Kaya Baru, teks anekdot, implikatur percakapan

\begin{abstract}
This research is qualitative descriptive research which aimed to describe the infraction of collaboration/cooperation principle and politeness principle in Orang Kaya Baru movie, to describe the meaning of implicature speech in this movie, and to describe its implementation on anecdote text learning. The methods of collecting data used in this research was listening method with recording technique for the basic technique, and the following technique of listening without speaking involvement and note taking technique. In analyzing data, the researcher used match method and element determining selection of
\end{abstract}


pragmatic technique, and the next technique was comparison relating technique. The result of analyzing data were presented through informal method. Based on data analysis, there are some infractions in every maxim in the principle of collaboration/cooperation and politeness principle. The maxim infractions above caused the conversation implicature in Orang Kaya Baru movie. Those infractions can give some advantages for the readers especially the students. Through the infractions of collaboration/cooperation principle, the students are able to use the collaboration/cooperation principle appropriately when they communicate each other. The understanding of implicature can be used as a teaching material to achieve the learning purpose of the basic competency (KD) 3.5 evaluating anecdote text from its hidden meaning.

Keyword: Orang Kaya Baru movie, anecdote text, conversation implicature

\section{PENDAHULUAN}

Penggunaan bahasa sebagai alat komunikasi dapat dipelajari secara formal dan informal. Secara formal penggunaan bahasa dapat dipelajari melalui dunia pendidikan, sedangkan secara informal salah satu cara yang digunakan adalah dengan memanfaatkan media audiovisual. Melalui media audiovisual, penggunaan bahasa secara verbal dan nonverbal dapat dilihat secara langsung. Salah satu media audiovisual yang dapat digunakan untuk mempelajari penggunaan bahasa adalah film. Film merupakan salah satu sarana hiburan yang banyak digemari masyarakat. Bahasa yang digunakan dalam film dapat menciptakan bahasa baru yang kebanyakan tidak sesuai dengan aturan kebahasaan yang baik dan benar. Sebagai makhluk sosial yang cenderung mudah meniru dan terpengaruh akan halhal baru yang didengar atau dilihat, manusia dapat dengan mudah menirukan bahasa baru yang muncul dalam sebuah film dan menggunakannya dalam kehidupan sehari-hari.

Film berisi tuturan percakapan antartokoh yang berperan sesuai bagiannya. Menurut Gunarwan (dalam Rustono:57), dalam setiap tuturan selalu ada makna atau pesan yang ingin disampaikan oleh peserta tuturan. Namun, tidak lantas pesan-pesan tersebut ditunjukkan secara eksplisit kepada penonton, melainkan dapat disajikan secara implisit melalui percakapan-percakapan antartokohnya. Terkadang, tidak semua orang dapat mengerti dan memahami pesan tersirat yang disajikan dalam sebuah film. Begitupun dalam berkomunikasi, tidak semua mitra tutur dapat mengerti dan memahami makna-makna tersirat yang disampaikan oleh penutur dalam setiap ujarannya. Pesan tersirat dalam percakapan muncul karena adanya pelanggaran maksim-maksim dalam prinsip percakapan, baik prinsip kerja sama maupun prinsip kesantunan. Maka dari itu, dalam komunikasi diperlukan adanya kerja sama antara penutur dan lawan tutur agar tidak menimbulkan kesalapahaman karena apa yang dimaksudkan oleh penutur berbeda dengan apa yang dipahami oleh mitra tutur atau sebaliknya. Dalam ilmu 
pragmatik, kondisi seperti itu dapat diatasi dengan menggunakan analisis implikatur. Grice (dalam Niatri, 2016:4), mengungkapkan bahwa konsep implikatur dipakai untuk menerangkan perbedaan yang sering terjadi antara "apa yang diucapkan" dengan "apa yang diimplikasi”. Menurut Yule (2014:61), implikatur merupakan informasi yang memiliki makna lebih banyak daripada sekedar kata-kata dan makna tersebut merupakan makna tambahan yang ingin disampaikan oleh penuturnya.

Film Orang Kaya Baru yang disutradarai oleh Ody C. Harahap merupakan salah satu film dengan genre komedi yang menyajikan kisah realitas sosial yang biasa dialami oleh masyarakat. Film Orang Kaya Baru menceritakan tentang kehidupan sebuah keluarga yang tergolong apa adanya, bahkan cenderung susah dibandingkan keluarga lain di lingkungannya. Dikutip dari laman CNN Indonesia (2019), film Orang Kaya Baru ini layak untuk ditonton dan bisa menjadi pilihan film yang menghibur sekaligus mengingatkan hangatnya kebersamaan keluarga. Percakapan-percakapan yang disajikan mengandung banyak petuah yang dapat dijadikan sebagai renungan bagi penontonnya. Berdasarkan hasil observasi, tuturan-tuturan antartokoh dalam film ini diduga mengandung makna implisit atau tersirat. Banyaknya tuturan yang melanggar prinsip percakapan dalam film tersebut membuat peneliti tertarik untuk mengupas implikatur percakapan yang terkandung dalam film Orang Kaya Baru. Penyampaian pesan dalam sebuah film menggunakan adanya implikasi untuk membuat film lebih menarik dari segi bahasa.

Penelitian ini dapat diimplementasikan dalam pembelajaran Bahasa Indonesia di SMA. Salah satu pembelajaran Bahasa Indonesia terkait makna tersirat terdapat dalam materi teks anekdot kelas X yaitu pada KD 3.5 mengevaluasi teks anekdot dari aspek makna tersirat. Dalam pembelajaran tersebut, materi tentang implikatur dapat digunakan sebagai bahan ajar untuk mencari makna tersirat yang terdapat dalam sebuah teks anekdot. Berdasarkan hal tersebut, peneliti ingin mengkaji film Orang Kaya Baru dengan menggunakan kajian pragmatik terkait implikatur percakapan sebagai bahan ajar teks anekdot. Penelitian ini bertujuan untuk mendeskripsikan wujud pelanggaran prinsip kerja sama dan prinsip kesantunan dalam film Orang Kaya Baru, mendeskripsikan makna implikatur yang muncul dalam film Orang Kaya Baru, dan mendeskripsikan implementasi penelitian dalam pembelajaran teks anekdot.

Pragmatik merupakan cabang ilmu linguistik yang mengkaji tentang maksud suatu tuturan dengan memperhatikan konteks. Pragmatik juga memperhatikan dengan siapa ia berbicara (penutur dan lawan tutur), kapan (waktu), di mana (tempat), dan dalam keadaan apa (situasi/konteks). Konteks sangat penting dalam kajian pragmatik. Seperti yang telah diungkapkan pada pembahasan sebelumnya, pentingnya konteks dalam pragmatik ditekankan oleh Wijana (dalam Nadar, 2013:4), yang menyebutkan bahwa pragmatik mengkaji makna yang terikat konteks. Dengan adanya konteks akan sangat membantu mitra tutur dalam menafsirkan makna tuturan yang diucapkan oleh penutur karena konteks 
merupakan latar belakang terjadinya suatu pembicaraan antarpenutur, sehingga makna tuturan dapat dengan mudah dipahami oleh mitra tutur.

Yule (2014:60), dalam bukunya yang berjudul Pragmatik menjelaskan bahwa implikatur sangat erat kaitannya dengan prinsip kerja sama. Bentuk kerja sama yang dimaksudkan ialah kerja sama yang sederhana di mana orang-orang yang sedang berbicara umumnya tidak diasumsikan untuk berusaha membingungkan, mempermainkan, atau menyembunyikan informasi yang relevan satu sama lain. Dalam banyak peristiwa, jenis kerja sama ini hanya merupakan titik awal untuk menjelaskan apa yang dikatakan. Nadar (2013:24-26), yang menyatakan bahwa prinsip kerja sama adalah formulasi tentang prinsip umum dalam penggunaan bahasa yang diajukan oleh Grice. Selanjutnya, prinsip kerja sama ini dijabarkan lebih lanjut ke dalam empat maksim yaitu: 1) maksim kuantitas; 2) maksim kualitas; 3) maksim relevansi; dan 4) maksim cara/pelaksanaan.

Selain prinsip kerja sama, dalam berkomunikasi penutur juga perlu mematuhi prinsip kesantunan. Prinsip kesantunan diperlukan untuk melengkapi prinsip kerja sama dan mengatasi kesulitan yang timbul akibat penerapan prinsip kerja sama (Grice dalam Rustono, 1999:66). Gunarwan (dalam Rustono, 1999:66), menegaskan bahwa pelanggaran prinsip kerja sama adalah bukti bahwa dalam berkomunikasi tugas penutur tidak hanya untuk menyampaikan informasi saja, melainkan untuk menjaga dan memelihara hubungan sosial antara penutur dan mitra tutur. Leech (dalam Rustono, 1999:70) menjabarkan prinsip kesantunan ke dalam enam maksim yaitu: 1) maksim ketimbangrasaan; 2) maksim kemurahhatian; 3) maksim keperkenaan; 4) maksim kerendahhatian; 5) maksim kesetujuan; dan 6) maksim kesimpatian.

Anekdot merupakan cerita singkat yang menarik karena lucu dan mengesankan. Kelucuan tersebut terjadi karena adanya pelanggaran-pelanggaran prinsip percakapan yang mengakibatkan munculnya implikatur atau makna tersirat. Anekdot digunakan untuk menyampaikan kritik, tetapi tidak dengan cara yang kasar dan menyakiti. Anekdot mengangkat cerita tentang orang penting (tokoh masyarakat) atau terkenal berdasarkan kejadian yang sebenarnya. Kejadian nyata ini kemudian dijadikan dasar cerita lucu dengan menambahkan unsur rekaan. Seringkali, partisipan (pelaku cerita), tempat kejadian, dan waktu peristiwa dalam anekdot tersebut merupakan hasil rekaan. Meskipun demikian, ada juga anekdot yang tidak berasal dari kejadian nyata (Kemendikbud, 2017:107).

Penelitian terkait implikatur sebelumnya pernah dilakukan oleh beberapa peneliti terdahulu, di antaranya oleh Setyorini (2017), dalam jurnal bahtera yang berjudul "Deskripsi Implikatur Fenomena Meme di Instagram dan Implementasinya sebagai Bahan Ajar Teks Anekdot". Perbedaan penelitian ini dengan penelitian Setyorini yaitu terletak pada sumber data. Setyorini meneliti implikatur fenomena meme di instagram, sedangkan penelitian ini meneliti implikatur dalam film Orang Kaya Baru. Perbedaan kedua yaitu Setyorini tidak mengkaji pelanggaran prinsip kerja sama dan prinsip kesantunan, sedangkan 
penelitian ini mengkaji. Penelitian sejenis juga pernah dilakukan oleh Sakoikoi (2018), dalam skripsinya yang berjudul "Implikatur Percakapan Antartokoh dalam Film Tenggelamnya Kapal Van Der Wijck Karya Buya Hamka". Perbedaan penelitian Sakoikoi dengan penelitian ini terletak pada sumber data. Sakoikoi meneliti implikatur dengan objek film Tenggelamnya Kapal Van Der Wijck karya Buya Hamka, sedangkan penelitian ini menganalisis film Orang Kaya Baru. Perbedaan kedua yaitu Sakoikoi tidak mengkaji pelanggaran prinsip kerja sama dan prinsip kesantunan, sedangkan penelitian ini mengkajinya. Perbedaan yang ketiga yaitu terletak pada metode analisis data. Sakoikoi menganalisis data dengan cara mengidentifikasi, mengklasifikasikan, dan mendeskripsikan data, sedangkan penelitian ini menggunakan metode padan dengan teknik pilah unsur penentu dan teknik hubung banding. Wahyuningtiyas (2019), juga meneliti mengenai implikatur dalam skripsinya yang berjudul "Implikatur Percakapan dalam Novel Ayah Karya Andrea Hirata". Perbedaannya penelitian Wahyuningtyas dengan penelitian ini yaitu terletak pada sumber data.

\section{METODE PENELITIAN}

Penelitian ini merupakan salah satu jenis penelitian deskriptif kualitatif karena penelitian ini menghasilkan sebuah data yang berupa kata-kata biasa, bukan angka. Data dalam penelitian ini yaitu tuturan dalam film Orang Kaya Baru yang mengandung implikatur. Adapun sumber data dalam penelitian ini adalah film Orang Kaya Baru.

Pengumpulan data dalam penelitian ini dilakukan menggunakan metode simak dengan teknik dasar sadap dan teknik lanjutannya menggunakan teknik simak bebas libat cakap dan teknik catat. Data yang disimak dalam penelitian ini berupa tuturan-tuturan antartokoh dalam film Orang Kaya Baru yang mengandung implikatur percakapan. Pada tahap ini, peneliti mengambil data dengan cara melakukan penyadapan terhadap penggunaan bahasa secara lisan yaitu berupa tuturan-tuturan antartokoh dalam film Orang Kaya Baru yang diduga mengandung implikatur percakapan sehingga teknik lanjutan yang digunakan adalah teknik catat.

Metode yang digunakan oleh peneliti dalam tahap analisis data yaitu metode padan dengan teknik dasar pilah unsur penentu (PUP). Sesuai dengan jenis penentu yang akan dipilah-pilah, penelitian ini menggunakan daya pilah pragmatis. Menurut Kesuma, 2007:52, daya pilah pragmatis merupakan daya pilah yang alat penentunya berupa lawan tutur atau mitra wicara. Setelah data diperoleh, peneliti kemudian memilah tuturan yang mengandung pelanggaran prinsip kerja sama Grice dan prinsip kesantunan Leech agar dapat ditentukan implikatur percakapannya. Teknik lanjutan dari metode padan yaitu teknik hubung banding. Teknik hubung banding yang digunakan dalam penelitian ini yaitu teknik hubung banding memperbedakan (HBB). Peneliti membandingkan tuturan antar tokoh dalam film Film Orang Kaya Baru dengan aturan maksim dalam prinsip kerja sama dan prinsip kesantunan. 


\section{HASIL DAN PEMBAHASAN}

Percakapan antartokoh dalam film Orang Kaya Baru banyak mengandung pelanggaran-pelanggaran maksim dalam prinsip percakapan, baik prinsip kerja sama maupun prinsip kesantunan yang menyebabkan munculnya implikatur percakapan. Berikut merupakan jumlah pelanggaran tiap maksim:

Tabel 1. Pelanggaran Maksim

\begin{tabular}{|l|c|l|c|}
\hline \multicolumn{2}{|c|}{ Pelanggaran Prinsip Kerja Sama } & \multicolumn{2}{c|}{ Pelanggaran Prinsip Kesantunan } \\
\hline Maksim Kuantitas & 2 data & Maksim Ketimbangrasaan & 3 data \\
\hline Maksim Kualitas & 7 data & Maksim Kemurahhatian & 1 data \\
\hline Maksim Relevansi & 6 data & Maksim Keperkenaann & 3 data \\
\hline Maksim Cara & 2 data & Maksim Kerendahhatian & 2 data \\
\hline & & Maksim Kesetujuan & 3 data \\
\hline & & Maksim Kesimpatian & 2 data \\
\hline \multicolumn{1}{|c|}{ Jumlah data } & $\mathbf{1 7}$ data & Jumlah data & $\mathbf{1 4}$ data \\
\hline
\end{tabular}

Berikut contoh analisis data:

Konteks: Duta, Tika, dan Doni pergi ke sebuah pesta penikahan mengendarai motor dengan berbonceng tiga. Padahal mereka tahu jika peraturan lalu lintas di Indonesia melarang untuk membawa penumpang lebih dari satu orang. Di perjalanan mereka berdebat mengenai siapa yang harus turun dari motor karena ternyata ada razia kendaraan. Akhirnya, Tika yang memutuskan untuk turun dan berjalan kaki di trotoar melewati polisi-polisi yang sedang melakukan razia pada pengguna motor. Duta meminta Tika untuk melepas helm yang dipakainya, tetapi Tika tidak mau melepasnya dengan alasan 'nanti juga bakal dipakai lagi'.

Polisi : "Kenapa pake helm, Dek?"

Tika : "Tertib lalu lintas, Pak."

Duta : "Kalau jalan kaki ngga perlu Dek, apalagi di trotoar."

Polisi : "Trotoar kan juga ngga aman, Pak."

Pada percakapan tersebut, tuturan Tika dianggap melanggar maksim kualitas dalam prinsip kerja sama Grice, karena Tika mengatakan sesuatu yang tidak benar. Anggapan tersebut sesuai dengan aturan dalam maksim kualitas "jangan mengatakan sesuatu yang tidak benar dan jangan mengatakan sesuatu yang kebenarannya tidak dapat dibuktikan secara memadai". Sebagaimana yang kita ketahui selama ini, helm hanya dipakai pada saat berkendara, bukan untuk dipakai pejalan kaki. Pengetahuan tersebut sekaligus menjadi bukti jika Tika mengatakan sesuatu yang salah.

Tuturan Tika dalam percakapan tersebut berisi pesan tersirat bahwa 'Tika telah melanggar tata tertib lalu lintas'. Tika sadar jika dia mengatakan "tertib lalu lintas" bukan semata-mata karena Ia memang mematuhi peraturan lalu lintas, tapi 
karena Ia terpaksa harus mengalah dari adiknya dan harus berjalan kaki melewati polisi. Tika juga tahu jika berjalan kaki sebenarnya tidak perlu memakai helm, ia tetap memakainya karena merasa malas melepasnya. Pada konteks juga dijelaskan bahwa Tika tidak melepas helmnya bukan karena tertib lalu lintas, tapi karena kakaknya, Duta melanggar lalu lintas dengan membawa penumpang lebih dari satu sehingga mengharuskan Tika untuk berjalan kaki melewati polisi yang sedang bertugas dan Ia merasa repot jika harus melepas helm karena nantinya akan dipakai lagi jika sudah melewati polisi.

Konteks: Duta datang ke sebuah kafe mengenakan T-shirt untuk menemui seseorang yang bersedia mendanai pementasan teaternya. Akan tetapi, di pintu masuk Ia dilarang masuk oleh penjaga karena peraturan kafe mengharuskan pengunjung memakai pakaian rapi dan tidak boleh T-shirt. Duta disuruh untuk menunggu temannya di luar.

Resepsionis : "Malam Pak."

Duta : "Ah, tai."

Satpam : : "Mas kenapa sih? Nggak sopan begitu."

Duta : "Ngapain gue sopan sama orang-orang yang ngejual bangsanya sendiri, buat apa hah?"

Satpam : "Maksudnya?"

Duta : "Elu tadi ama bule lu hormat hormat, ama orang sendiri lu injekinjek. Kan anjing!"

Satpam : : "Saya makin nggak ngerti Mas ngomong apa."

Maksim cara menghendaki penutur untuk mengatakan sesuatu secara jelas dan mudah dimengerti. Tuturan Duta dalam percakapan di atas dianggap telah melanggar maksim cara dalam prinsip kerja sama Grice. Duta mengatakan sesuatu yang membingungkan mitra tuturnya sehingga dalam percakapan tersebut, tuturan Duta melanggar aturan dalam maksim cara. Jika tuturan Duta jelas, maka mitra tutur tidak akan menanggapi tuturan Duta dengan mengatakan "maksudnya", yang berarti mitra tutur meminta Duta untuk menjelaskan maksud dari tuturannya. Bahkan, ketika Duta sudah memberikan penjelasan, mitra tutur pun semakin tidak mengerti dengan apa yang diujarkan oleh Duta.

Melalui tuturannya, Duta mengungkapkan sikap marah. Duta kesal karena Ia dilarang masuk kafe dengan memakai T-shirt, tetapi ketika Dia keluar dari kafe Dia melihat ada seorang bule yang memakai T-shirt yang justru disambut dengan ramah oleh penjaga kafe. Duta merasa tidak dihargai oleh orang-orang bangsanya sendiri. Menurutnya, orang-orang tersebut telah menjual bangsanya sendiri karena lebih hormat pada bule.

Konteks: Duta sedang memperlihatkan kepada teman-temannya sebuah panggung pementasan megah yang akan menjadi tempat penyelenggaraan sebuah karya ciptaannya. Namun, temannya-temannya tidak percaya dan menganggap Duta 
sedang bercanda karena mereka sadar jika mereka tidak akan mampu menyewa gedung pementasan tersebut.

Duta : "Di Sini nih master peace kita bakal dipentasin."

Ardi : "Duta Duta lu becanda kan?"

Duta : "Mimpi boleh dong?"

Wawan : "Tapi jangan kelamaan juga sih ta, ngga bagus."

Duta : "Lu berdua tuh ngga punya nyali. Lu tau ngga? Dunia itu Cuma bisa diubah sama pemimpi."

Tuturan Duta dalam data di atas melanggar maksim ketimbangrasaan dalam prinsip kesantunan Leech. Maksim ketimbangrasaan berisi nasihat agar penutur meminimalkan biaya kepada pihak lain dan memaksimalkan keuntungan kepada pihak lain. Duta dengan sifat sombongnya sedang menunjukkan kepada temantemannya jika Dia akan menggelar sebuah karya ciptanya di gedung megah yang harga sewanya milyaran rupiah. Duta mengatakan "Lu berdua tuh ngga punya nyali. Lu tau ngga? Dunia itu Cuma bisa diubah sama pemimpi" ketika temantemannya menganggap Duta sedang bercanda dan bermimpi perihal membuat pementasan di gedung megah nan mahal. Tuturan "Lu berdua tuh ngga punya nyali" sangat tidak menguntungkan bagi teman-temannya selaku mitra tutur. Duta menuturkan jika kedua temannya tidak memiliki keberanian untuk mengambil resiko, untuk bermimpi setinggi-tingginya, yang artinya Duta menganggap jika teman-temannya adalah seorang pengecut. Jika dibandingkan dengan nasihat dalam maksim ketimbangrasaan, maka tuturan Duta tidak sejalan karena tuturan Duta tidak memaksimalkan keuntungan kepada pihak lain.

Makna tambahan yang ingin disampaikan oleh Duta dalam tuturannya adalah bahwa Duta merupakan seorang pemimpi yang akan mengubah dunia, Dia akan mementaskan karyanya di gedung megah yang tidak akan pernah disangka oleh orang-orang. Melalui tuturannya, Duta menganggap jika teman-temannya tidak punya nyali untuk menjadi seorang pemimpi yang memimpikan sebuah karyanya dipentaskan di gedung megah tersebut. Bagi Duta dunia itu hanya bisa diubah oleh pemimpi dan Duta merupakan salah satu pemimpi itu.

Implementasi hasil penelitian dalam pembelajaran bahasa Indonesia yaitu hasil penelitian ini dapat dijadikan sebagai bahan ajar teks anekdot. Dalam pembelajaran tersebut, materi tentang implikatur dapat digunakan sebagai bahan ajar untuk mencari makna tersirat yang terdapat dalam sebuah teks anekdot. Materi mengenai makna tersirat (implikatur) dan prinsip percakapan beserta pelanggarannya dapat digunakan sebagai bahan ajar untuk mencapai tujuan pembelajaran dari Kompetensi Dasar (KD) 3.5 yaitu mengevaluasi teks anekdot dari aspek makna tersirat. Melalui KD tersebut, siswa dituntut untuk dapat mengevaluasi teks anekdot dari aspek makna tersirat. Salah satu cara untuk mengetahui makna tersirat dalam teks anekdot yaitu melalui pemaknaan implikatur percakapan. Adapun pemaknaan implikatur dapat diidentifikasi melalui telaah konteks. Konteks merupakan situasi atau sebab/alasan yang melatarbelakangi terjadinya suatu komunikasi/percakapan. Menurut Mulyana 
(2005:22), salah satu unsur konteks yang cukup berpengaruh terhadap makna adalah waktu dan tempat. Siswa dapat menentukan konteks dengan cara mengamati latar, situasi, dan peserta tuturan. Saat siswa dapat memahami dan memaknai percakapan dengan baik, maka tujuan Kompetensi Dasar tersebut akan mudah dicapai.

\section{PENUTUP}

\section{Simpulan}

Berdasarkan hasil analisis data dan pembahasan terhadap implikatur percakapan dalam film Orang Kaya Baru sebagai bahan ajar teks anekdot kelas X, dapat disimpulkan bahwa percakapan antartokoh dalam film Orang Kaya Baru banyak mengandung pelanggaran-pelanggaran maksim dalam prinsip percakapan, baik prinsip kerja sama maupun prinsip kesantunan yang menyebabkan munculnya implikatur percakapan. Bentuk pelanggaran prinsip percakapan paling banyak ditemukan pada prinsip kerja sama Grice yaitu sebanyak 17 data. Ditemukan pelanggaran dalam maksim kuantitas sebanyak 2 data, maksim kualitas sebanyak 7 data, maksim relevansi sebanyak 6 data, dan pelanggaran maksim cara sebanyak 2 data. Adapun dalam prinsip kesantunan ditemukan 14 data yang melanggar maksim-maksim dalam prinsip kesantunan. Ditemukan pelanggaran dalam maksim ketimbangrasaan sebanyak 3 data, maksim kemurahhatian sebanyak 1 data, maksim keperkenaan sebanyak 3 data, maksim kerendahhatian sebanyak 2 data, maksim kesetujuan sebanyak 3 data, dan pelanggaran maksim kesimpatian sebanyak 2 data.

Adapun makna implikatur percakapan yang muncul dalam film Orang Kaya Baru akibat pelanggaran maksim-maksim diantaranya, penyombongan diri, pengakuan, penolakan, ketidaktahuan, kekecewaan, pelanggaran, gurauan, kebohongan, harapan, kemarahan, ketidakpercayaan, ketidakinginan, keyakinan, penolakan, keluhan, ketidakterimaan, mengejek, ketidaksukaan, dan kekesalan.

Implementasi hasil penelitian dalam pembelajaran bahasa Indonesia yaitu hasil penelitian ini dapat dijadikan sebagai bahan ajar teks anekdot. Dalam pembelajaran tersebut, materi tentang implikatur dapat digunakan sebagai bahan ajar untuk mencari makna tersirat yang terdapat dalam sebuah teks anekdot KD 3.5 yaitu mengevaluasi teks anekdot dari aspek makna tersirat. Melalui KD tersebut, siswa dituntut untuk dapat mengevaluasi teks anekdot dari aspek makna tersirat. Salah satu cara untuk mengetahui makna tersirat dalam teks anekdot yaitu melalui telaah konteks.

\section{Saran}

Hasil penelitian ini diharapkan dapat dijadikan sebagai bahan rujukan bagi penelitian selanjutnya dalam menganalisis tuturan secara pragmatik. Peneliti berharap masyarakat umum dapat menerapkan prinsip-prinsip percakapan yang perlu dipatuhi dalam berkomunikasi agar terjalin komunikasi yang kooperatif. Berdasarkan kesimpulan dari hasil penelitian ini, peneliti menyarankan agar 
dilakukan penelitian lain yang serupa dengan menggunakan sumber data yang berbeda seperti novel, cerpen, percakapan sehari-hari, atau talk show agar dapat memperluas kajian pragmatik mengenai implikatur. Bagi guru bahasa indonesia, peneliti berharap hasil penelitian ini dapat dijadikan sebagai bahan ajar dalam mengungkap makna tersirat suatu tuturan.

\section{DAFTAR PUSTAKA}

Arikunto, Suharsimi. 2010. Prosedur Penelitian Suatu Pendekatan Praktik. Jakarta: Rineka Cipta.

Chaer, Abdul. 2014. Linguistik Umum. Jakarta: Rineka Cipta.

CNN Indonesia. 2019. https://m.cnnindonesia.com/hiburan/20190125175546-220363916/ulasan-film-orang-kaya-baru. Diakses 16 Januari 2020 Pukul 10.16 WIB.

Cummings, Louise. 2007. Pragmatik: Sebuah Perspektif Multidisipliner. Yogyakarta: Pustaka Pelajar.

Ilham, Mughnifar. 2019. "Teks anekdot-pengertian, ciri, struktur, kaidah, tujuan, dan contoh". https://materibelajar.co.id/teks-anekdot/. Diakses 12 Maret 2020 pukul 2.28 WIB.

Kementerian Pendidikan dan Kebudayaan Republik Indonesia. 2017. Buku Guru Bahasa Indonesia Edisi Revisi 2017 SMA/MA/SMK/MAK Kelas X. Jakarta: Pusat Kurikulum dan Perbukuan, Balitbang, Kemendikbud.

Kesuma, Tri Mastoyo Jati. 2007. Pengantar (Metode) Penelitian Bahasa. Yogyakarta: Carasvatibooks.

Mahsun. 2007. Metode Penelitian Bahasa: Tahapan, Strategi, dan Tekniknya. Jakarta: PT Rajagrafindo Persada.

Moleong, Lexy J. 2015. Metodologi Penelitian Kualitatif. Bandung: PT Remaja Rosdakarya.

Mulyana. 2005. Kajian Wacana Teori, Metode, dan Aplikasi Prinsip-Prinsip Analisis Wacana. Yogyakarta: Tiara Wacana.

Nadar, F. X. 2013. Pragmatik dan Penelitian Pragmatik. Yogyakarta: Graha Ilmu.

Niatri, Adven Desi. 2016. "Implikatur Percakapan Antartokoh dalam Film Marmut Merah Jambu Karya Raditya Dika”. Skripsi. Yogyakarta: Fakultas Keguruan dan Ilmu Pendidikan, Universitas Sanata Dharma. Https://scholar.google.co.id/scholar?hl=id\&as_sdt=0\%2C5\&q=implikatur $+p$ ercakapan+dalam+film+marmut+merah+jambu. Diunduh 13 Desember 2019 Pukul 09.44 WIB.

Sukhdev Singh dan Wickey V. Olindo "produser". 2019. Orang Kaya Baru. Screenplay Films, Legacy Pictures: Jakarta. 1 jam 32 menit.

Pageyasa, Wayan dan Nur Ihsan. 2019. Kekerasan Bahasa di Media Daring Nasional. Yogyakarta: Deepublish.

Putrayasa, Ida Bagus. 2014. Pragmatik. Yogyakarta: Graha Ilmu.

Rustono. 1999. Pokok-Pokok Pragmatik. Semarang: CV. IKIP Semarang Press. 
Sakoikoi, Mery Cristi Esvinoza. 2018. "Implikatur Percakapan dalam Film Tenggelamnya Kapal Van Der Wijck Karya Buya Hamka”. Skripsi. Yogyakarta: Fakultas Keguruan dan Ilmu Pendidikan, Universitas Sanata Dharma.Https://scholar.google.co.id/scholar?hl=id\&as_sdt=0\%2C5\&q=impli katur+percakapan+dalam+film+tenggelamnya+kapal+van+der+wijck.

Diunduh 13 Desember 2019 Pukul 09.44 WIB.

Setyorini, Ririn. 2017. "Deskripsi Implikatur Fenomena Meme di Instagram dan Implementasinya Sebagai Bahan Ajar Teks Anekdot”. Jurnal Bahtera, (4) 8, 130-143. Http://ejournal.umpwr.ac.id/index.php/bahtera/article /view/4159/0. Diunduh 1 Oktober 2019 Pukul 01.22 WIB.

Sudaryanto. 2015. Metode dan Aneka Teknik Analisis Bahasa (Pengantar Penelitian Wahana Kebudayaan secara Linguis). Yogyakarta: Sanata Dharma University Press. Wahyuningtyas, Septi. 2019. "Implikatur Percakapan dalam Novel Ayah Karya Andrea Hirata". Skripsi. Purwokerto: Fakultas Ilmu Budaya, Universitas Jenderal Soedirman.

Yule, George. 2014. Pragmatik. Terjemahan oleh Indah Fajar Wahyuni. Yogyakarta: Pustaka Pelajar. 